\title{
SAFE MOTHERHOOD PRACTICE IN DALIT COMMUNITY
}

\author{
Subhash Prasad \\ Department of Health \& Physical Education, T.U., TRM Campus, Birgunj
}

\begin{abstract}
Safe motherhood practice is still poor among the unprivileged groups like the Dalit of Nepal. Low socio-economic condition and lack of awareness in the Dalit community seems to have negative impact on women health and safe motherhood practice. This paper describes the practice of safe motherhood in the Dalit community based on quantitative data collected from 120 mothers. The respondents were interviewed by using interview schedule. It is concluded that lack of education and awareness, low socioeconomic condition, teenage marriage and early pregnancy, improper antenatal care service, unsafe delivery at home, improper postnatal checkup and traditional attitudes indicate that safe motherhood practice is not satisfactory in the Dalit community.
\end{abstract}

\section{Keywords}

Safe motherhood, age at marriage, first pregnancy, delivery care, postnatal care.

\section{Introduction}

Safe motherhood is a matter of human rights and social justice. It is a great challenge for the whole world to make safe motherhood a reality. Different NGOs and INGOs and the governments of both developed and developing countries, are making enormous efforts to reduce maternal mortality and morbidity. The most important thing is that the goals of safe motherhood practice will not be achieved unless women are accorded empowerment and their human rights are recognized which includes their rights to quality services, sound medical advices during pregnancy and child delivery.

Since the launching of the global safe motherhood initiated in 1987, there has been a dramatic worldwide increase in attention of the problem of maternal mortality and morbidity. A second important movement was the 1990's world Summit for children, sponsored by UN and organized by UNICEF. 
In the world summit for children declaration and Plant of Action one of the seven major goals was to decrease the maternal mortality by half between 1990 and the year 2000 A.D. This goal was re-emphasized at the 1994, ICPD held in Cairo, and the 1995 fourth world conference on women in Beijing (UNICE, 1997).

According to the definition suggested by Feurstein (1993), "Safe motherhood means creating the circumstances with in which a women is able to choose whether she becomes pregnant, and if she does, ensuring that she receives care for prevention and treatment of pregnancy complications, that she has access to trained birth assistance and if she needs it to emergency obstetric care, and care after birth, to prevent death or disability from complications of pregnancy and child birth. Feurstein also suggested eight keys to safe motherhood such as provision of essential obstetric services, effective referral mechanisms, proper antenatal care and risk detection, trained delivery and postnatal care, availability of family planning information and services, delayed marriage and childbirth, provision of nutritious food and proper care for baby girls, Increased female literacy (cited in Pudasaini, 1994).

Maternal mortality has been a leading cause of death among women of reproductive age in developing countries. More than half million women die every year during pregnancy and child birth. Of the estimated total of 536000 maternal deaths worldwide, developing countries accounted for $99 \%$ (533 oo) of the deaths (WHO, UNICEF, UNFPA \& World Bank, 2007). Material mortality is still high in Nepal. According to Nepal Demographic Health Survey, the country experiences 281 maternal deaths per 100, ooo live births. As per the report of MOHP, New ERA \& Macro International Inc. 2007, poor maternal care during pregnancy and delivery are responsible for high maternal mortality. More than 80 percent births were delivered at home and 44 percent mothers received antenatal care from skilled birth attendants for their recent births in the five years preceding the survey (cited in Thapa, 2010).

Safe motherhood is a vital component of reproductive health and prime concern with fertility. Women deserve best possible health care to go through a happy and healthy pregnancy and child birth. Safe pregnancy, safe delivery and safe birth of new born are the major components of safe motherhood. If mother is healthy during pregnancy and after delivery and then, the infant may be healthy. Safe motherhood practice such as regular antenatal checkup during pregnancy, institutional and skilled birth attendants, immunization of pregnant women against tetanus and early referral of complication can be helpful to reduce maternal mortality. Main objective of safe motherhood program in Nepal is to reduce mortality rate of women during pregnancy, natal and post natal period (FHD, 1998).

Dalit community is known to have unprivileged group and they remain to cut the main steam of the society. Dalit communities excluded socially, economically and politically in Nepal. Generally, Dalits are poor and illiterate in countryside. They are deprived of education, employment, communication, health status, leadership etc. Dalit community has faced different types of health problems including safe motherhood problem due to lack of above mentioned opportunities.

\section{Methods}

The paper is based on the study conducted in Kalaiya Municipality of Bara district. The respondents were the Dalits: Dom, Dusad, Chamar and Lohar. There were 197 mothers who had at least one child of under 5 years. Among them almost 6o percent (120) mother were selected by stratified sampling method. The interview schedule as the major tool was adopted to get information on safe motherhood practice of the Dalit women. 
In the process of data collection, sampled mothers were interviewed. The data were analyzed by using percentage.

\section{Results and discussion}

\section{Educational and economical condition}

Education plays vital role to maintain safe motherhood practice. The poor education attainment can be risk on maternal and child health. Data reveals that out of the 120 respondents, 58.33 percent were illiterate, 23.33 percent were only literate, 8.33 percent were up to primary level, 8.33 percent were up to secondary level and only 1.68 percent were up to intermediate level. The information reveals that respondents had not better education. Economic activity is one of the strong indicator of national development. Occupation is also related with the economic activities it help to change the life style of people. In this regard out of 120 respondents, 41.55 percent of respondents were engaged in agriculture, 20 percent were daily wages labor, 36.67 percent were housewives and 1.67 percent of them were in the Government service. Most of the respondents had not permanent income. Data reveals that they had no sufficient money for purchasing nutritional food and antenatal, natal and postnatal service during pregnancy. Their income was not enough to support for their livelihood and safe motherhood services.

\section{Age at marriage and first pregnancy}

Age at marriage and first pregnancy also plays a vital role of reproductive health as well as maintain safe motherhood practice. It is most important factors determining safe motherhood practice. Early marriage is mostly prevailing in Nepal due to various religious and cultural reasons. Most Nepali women are married before they reached eighteen.

Out of 120 respondents, 31.67 percent of respondents were married at the age of below 15 years, more than half ( $53.33 \%)$ were found at the age of $15-19$ and 15 percent were 20-24 years. Among 120 respondents, 15 percent women were pregnant at the age of below 15 years. Similarly, two third (68.33\%) of them were found at the age of 15-19 year, 33.33 percent were age at 20-24 years and 3.34 percent were 25-29 years. Early pregnant practice is prevailing in this community. It was found that most of the women (88.33\%) become pregnant before they reached the age of twenty due to early marriage practice as well as lack of knowledge about appropriate age for child bearing.

Antenatal care practice

Antenatal care is the care of women during pregnancy. The primary aim of antenatal care is to achieve a healthy mother and a healthy baby. Ideally this care should begin soon after conception and continue throughout pregnancy. Antenatal checkups detect the complication and suggest mother to stay safe from such complications (park, 1997). During pregnancy period at least four visits are necessary (DoHS, 2010). The following table 1 shows the antenatal visit and frequency of visit.

Table 1: Antenatal Visit

\begin{tabular}{|l|c|c|}
\hline Antenatal Visit & Number & Percentage \\
\hline yes & 70 & 58.33 \\
\hline No & 50 & 41.67 \\
\hline Total of & 120 & 100 \\
\hline $\begin{array}{l}\text { Frequency } \\
\text { Antenatal Visit }\end{array}$ & 12 & 24 \\
\hline One time & 12 & 24 \\
\hline Two times & 12 & 24 \\
\hline Three times & 14 & 28 \\
\hline $\begin{array}{l}\text { Four times and } \\
\text { more }\end{array}$ & 50 & 100 \\
\hline Total & \\
\hline
\end{tabular}

Table 1 shows that more than half (58.33\%) of total respondents were found visiting for antennal checkups and 41.67 percent respondents mothers did not receive any 
antenatal checkup. Among the antenatal visitors, 24 percent of them visited one time. Similarly 24 percent visited two times and 24 percent visited three times and rest 28 percent of them completed all four visits. Data reveal that among 120 mothers only 14 (11.66\%) mother were visiting four times of antennal check up. Antenatal checkup practice was even poor in this community due to lack of knowledge as well as poor socio-economic status.

Table 2: Taking T.T. Vaccine

\begin{tabular}{|l|c|c|}
\hline $\begin{array}{l}\text { Taking T.T. } \\
\text { Vaccine }\end{array}$ & Number & Percentage \\
\hline Yes & 54 & 45 \\
\hline No & 120 & 55 \\
\hline Total not & & \\
\hline $\begin{array}{l}\text { Cause of } \\
\text { taking T.T. vaccine }\end{array}$ & 16 & \\
\hline Lack of knowledge & 7 & 21.21 \\
\hline Lack of Time & 10 & 30.30 \\
\hline Traditional view & 33 & 100 \\
\hline Total &
\end{tabular}

During the pregnancy period, the tetanus toxoid vaccine is an important component of antenatal care. Every pregnant woman should take T.T. vaccine for prevent of neonatal tetanus (DoHS, 2010). Table 2 shows that 45 percent of mothers had taken T.T. at the pregnancy period and more than half (55\%) had not taken T.T. vaccine. Among them almost 49 percent mothers had not taken T.T. vaccine due to lack of knowledge, almost 21 percent mothers said, lack of time and almost 30 percent mothers said, due to traditional concept. Researcher also found that among T.T. receivers, most of the mothers had taken T.T. vaccine randomly due to lack of knowledge about importance of T.T. vaccine.

Micro nutrient i.e. folic acid deficiency is an important cause of nutritious anemia among pregnant women. Folic acid deficiency is known to use for abortion and fetal abnormalities (Adhikari and Krants, 2007). It was found that 51.67 percent mothers had taken folic acid tablets and 48.33 percent had not taken folic acid tablets during pregnancy period. Researcher found that lack of knowledge about importance of folic acid tablets in study population. Nutritious food is important for pregnant mother and the development of fetus. It prevents anemia and other nutritional deficiency diseases. So, it is essential to take additional nutritious food during pregnancy period. It was found that 56.67 percent of total respondent mothers had taken additional nutritious food during pregnancy while 43.33 percent of respondents had not taken additional food.

\section{Delivery care practice}

Delivery practice is one of the important factors for mother and infant life. Safe delivery practice is essential because it reduces delivery complication and saves mothers' as well as child's health (DoHS, 2010). Table 3 shows place of delivery assistance during delivery and umbilical cord cutting practice.

Table 3: Delivery Care Practice

\begin{tabular}{|l|c|c|}
\hline $\begin{array}{c}\text { Place of Deliv- } \\
\text { ery }\end{array}$ & Number & $\begin{array}{c}\text { Percent- } \\
\text { age }\end{array}$ \\
\hline Home & 84 & 70 \\
\hline Hospital & 36 & 30 \\
\hline Total & 120 & 100 \\
\hline $\begin{array}{l}\text { Assistance during } \\
\text { delivery at home }\end{array}$ & 28 & 33.33 \\
\hline Family member & 52 & 61.90 \\
\hline TBA/FCHV & 4 & 4.77 \\
\hline MCHW/Nurse & 84 & 100 \\
\hline Total & & \\
\hline $\begin{array}{l}\text { U m b i l i c a l } \\
\text { cord cutting } \\
\text { instrument } \\
\text { home }\end{array}$ & 84 & 57.14 \\
\hline New blade & 28 & 33.33 \\
\hline Old blade & 8 & 9.53 \\
\hline Other & & 100 \\
\hline Total & & \\
\hline
\end{tabular}


Table 3 shows that more than two third (70\%) of total respondents delivered their babies at home where as 30 percent of them delivered their babies at hospital. The data reveal that most of the mothers delivered their babies at home. In this regard medically it is not safe delivery for both mother and baby. If the delivery is in hospital or health clinic there is less chance of maternal and infant mortality. Regarding the assistance during delivery at home, out of 84 mothers, 33.33 percent babies delivered by family member where as 61.90 percent babies delivered by TBA/FCHV and remaining 4.77 percent babies delivered by MCHW/Nurse. Regarding the cord cutting instruments at home, out of 84 respondents, 87.14 percent did cords cutting by new blade where as 33.3 percent by old blade and remaining 9.53 percent did cords cutting by other instruments. This study reveals that the Dalit women are still practicing unsafe umbilical cord cutting practice. Such practice could increase the chance of neonatal tetanus and other infection.

\section{Postnatal Care Practice}

Postnatal care means care of mother and new born baby after delivery. Postnatal visit, nutritious food taking breast feeding and immunization are essential for promoting health of the mother and new born baby. National safe motherhood program recommends that mother should have a postnatal checkup within two days of delivery. This recommendation is based on the fact that a large number of maternal and neonatal death occur during the 48 hours after delivery $(\mathrm{MOH}, 2001)$. Postnatal visit shows in table 4 .
Table 4: Postnatal Visit

\begin{tabular}{|l|c|c|}
\hline \multicolumn{1}{|c|}{$\begin{array}{c}\text { Postnatal } \\
\text { Visit }\end{array}$} & Number & Percentage \\
\hline yes & 48 & 40 \\
\hline No & 720 & 60 \\
\hline Total of & 100 \\
\hline $\begin{array}{l}\text { Timing two } \\
\text { postnatal visit }\end{array}$ & 36 & 75 \\
\hline $\begin{array}{l}\text { Within tirst } \\
\text { days }\end{array}$ & 2 & 4.2 \\
\hline $\begin{array}{l}\text { Within two } \\
\text { week }\end{array}$ & 4 & 8.3 \\
\hline $\begin{array}{l}\text { Within } \\
\text { week }\end{array}$ & 6 & 12.5 \\
\hline After two week & 48 & 100 \\
\hline Total
\end{tabular}

Table 4 shows that 40 percent of respondents had taken postnatal checkup whereas 60 percent of respondents had not taken postnatal checkup. Among postnatal visitors, 75 percent had taken postnatal checkup within two days similarly $\mathbf{4 . 2}$ percent had taken within first week, 8.3 percent had taken within two weeks, 12.5 percent of mothers had taken postnatal checkup after two weeks. The data reveals that most of the respondents had not taken postnatal visit due to knowledge about postnatal checkup and low economic condition. Those mothers who had delivered their baby at hospital taken postnatal checkup within right time (within two days). After that Dalit women did not visit for postnatal checkup unless any complication.

It was found that out of 120 respondents, 56.67 percent mothers stopped breast feeding to their babies within one year where as 28.33 percent of them stopped within two years and remaining 15 percent stopped after two years. Among the 68 mothers who stopped breast feeding within one year, 70.5 percent of them said due to next pregnancy whereas 23.5 percent mothers had insufficient milk and remaining 6 percent said due to lack of time. The above data reveals that appropriate birth 
spacing and proper nutrition practice was very poor in the Dalit community.

\section{Conclusion}

It may be concluded that illiteracy, low socioeconomic condition, lack of awareness about proper age of marriage and first pregnancy were major accountable factors that lead to the poor safe motherhood practice in the Dalit community. Most of the respondents simply ignore the practices concern to the safe motherhood like proper antenatal checkup, administering T.T. vaccine and folic acid tablets during pregnancy despite being availability of health services. Unsafe home delivery practice still prevalent in this community and they were also using unsterile instrument to cut umbilical cord. Most of the respondents were not taking proper postnatal service and whereas most of mothers stopped breast feeding to their babies within one year due to next pregnancy and insufficient milk production. Therefore, it is recommended for the concerned authority and health service providers to organize health education and awareness programs about appropriate age of marriage and pregnancy, pregnancy care, complication of unsafe delivery at home, utilization of service during postnatal period.

\section{References}

Adhikari, R.K. \& Krantz, M.E. (2001). Child Nutritious and Health ( $3^{\text {rd }}$ ed). Kathmandu: Health Learning Material Centre.

DoHS (2010). Annual Report 2066/2067. Kathmandu: Department of Health Services.

FHD (1998). Safe motherhood policy. Kathmandu: Department of Health Service.

MoH (2001). Nepal Demographic and Health Survey. Kathmandu: Author.

Park, K. (1997). Park's Textbook of Preventive and Social Medicine (15 $5^{\text {th }}$ ed.). Jabalpur: M/S Banarsidas Bhanot.

Pudasaini, S.P. (1994). Safe motherhood challenges: The global and the Nepalese prospective. Nepal Population Journal, 3, 39-44.

Thapa, K.B. (2010). Safe motherhood practice of Tharu mother. Journal of Health Promotion, 3 , 39-45.

UNICEF, (1997). Guideline for Monitoring the Availability and use of Obstetric Service. New York: UNICEF.

World Bank, (2007). Maternal Mortality in 2005. Geneva: Author. 